\title{
Payments by US pharmaceutical and medical device manufacturers to US medical journal editors: retrospective observational study
}

\author{
Jessica J Liu, ${ }^{1,2}$ Chaim M Bell, ${ }^{1,2,3,4}$ John J Matelski, ${ }^{2}$ Allan S Detsky, ${ }^{1,2,3}$ Peter Cram ${ }^{1,2,3,4}$
}

${ }^{1}$ Department of Medicine,

University of Toronto, Toronto,

Ontario, Canada

${ }^{2}$ Department of Medicine,

Division of General Internal

Medicine, University Health

Network and Sinai Health

System, Toronto, Ontario,

Canada

${ }^{3}$ Institute for Health Policy,

Management, and Evaluation,

University of Toronto, Toronto,

Ontario, Canada

${ }^{4}$ Institute for Clinical and

Evaluative Sciences, Toronto,

Ontario, Canada

Correspondence to: J J Liu

jessica.liu@uhn.ca

Additional material is published online only. To view please visit the journal online.

Cite this as: BMJ 2017;359:j4619 http://dx.doi.org/10.1136/bmj.j4619

Accepted: 18 September 2017

\section{ABSTRACT}

OBJECTIVE

To estimate financial payments from industry to US journal editors.

DESIGN

Retrospective observational study.

SETTING

52 influential (high impact factor for their specialty)

US medical journals from 26 specialties and US Open

Payments database, 2014.

\section{PARTICIPANTS}

713 editors at the associate level and above identified from each journal's online masthead.

\section{MAIN OUTCOME MEASURES}

All general payments (eg, personal income) and research related payments from pharmaceutical and medical device manufacturers to eligible physicians in 2014. Percentages of editors receiving payments and the magnitude of such payments were compared across journals and by specialty. Journal websites were also reviewed to determine if conflict of interest policies for editors were readily accessible.

\section{RESULTS}

Of 713 eligible editors, 361 (50.6\%) received some ( \$0) general payments in 2014, and 139 (19.5\%) received research payments. The median general payment was $\$ 11$ ( $f 8$; $€ 9$ ) (interquartile range $\$ 0-2923)$ and the median research payment was $\$ 0$ (\$0-0). The mean general payment was \$28136 (SD \$415 045), and the mean research payment was $\$ 37963$ (SD \$175 239). The highest median general payments were received by journal editors from endocrinology $(\$ 7207, \$ 0-85816)$, cardiology (\$2664, \$0-12 912), gastroenterology (\$696, $\$ 0-20002)$, rheumatology $(\$ 515, \$ 0-14280)$, and

\section{WHAT IS ALREADY KNOWN ON THIS TOPIC}

Academic journals have made major efforts to ensure that authors disclose potential conflicts of interest

However, less attention has been paid to potential conflicts of interest by journal editors, who play a crucial role in deciding which manuscripts are published

\section{WHAT THIS STUDY ADDS}

Industry payments to journal editors are not rare, can be of substantial monetary value, and vary substantially between journals and by specialty

This study used publicly available US government data (Open Payments) rather than physician self report, which provides more accurate data on industry payments to journal editors

Journal editors should reconsider their conflict of interest policies and the impact that editor relations with industry may have on public trust in the research

enterprise urology (\$480, \$90-669). For high impact general medicine journals, median payments were $\$ 0$ (\$0-14). A review of the 52 journal websites revealed that editor conflict of interest policies were readily accessible (ie, within five minutes) for $17 / 52$ (32.7\%) of journals.

\section{CONCLUSIONS}

Industry payments to journal editors are common and often large, particularly for certain subspecialties. Journals should consider the potential impact of such payments on public trust in published research.

\section{Introduction}

Journal editors play a crucial role in scientific discourse. ${ }^{12}$ Editors triage new manuscript submissions and decide on those that warrant external review. For manuscripts that undergo external assessment, editors typically synthesise comments and decide which papers will be published. ${ }^{3}$ Based on concerns about lapses in integrity and unintentional bias associated with industry funding, ${ }^{4-6}$ authors are now required to comprehensively report financial relations with industry to editors early in the publication process. However, compared with author conflict of interest, editorial conflict of interest has been infrequently studied. $^{7-15}$

For authors, publication in top tier journals plays a crucial role in obtaining grant funding and career advancement. ${ }^{16}$ For industry, publication in high impact journals bestows academic prestige and global attention to research and may speed regulatory approval, boost sales, and increase stock price. ${ }^{1718}$ Journal editors wield enormous power; they are the individuals who determine a substantial amount of the content and conclusions of what appears in their journals, including article selection, article content, and which articles have accompanying editorials.

Despite efforts to improve transparency, the peer review process often seems opaque to those on the outside. $^{19} 20$ In recent years, journal editors have responded to concerns by publishing more information related to the publication process, including authors' financial disclosures (eg, International Committee of Medical Journal Editors (ICJME) authorship forms), study protocols, statistical codes, and even source data. ${ }^{21-23}$ Certain journals have moved to an open review process in which external peer review critiques, editorial comments, and author responses are published online to maximise transparency of the review process. ${ }^{24} 25$ Improvements notwithstanding, the inner workings and decision making processes of editors remain a mystery to readers, authors, and 
the public. Authors have been expected to disclose financial relations using ICMJE conflict of interest forms at most reputable journals since 2010; however, financial disclosure requirements for editors remain highly variable. ${ }^{6} 12 \quad 13 \quad 21-23$ Professional societies such as the ICMJE, the World Association of Medical Editors (WAME), and the Committee on Publication Ethics (COPE) have published recommendations on editorial conflicts of interest. ${ }^{26-28}$ However, only 30$50 \%$ of high impact biomedical journals have clear editorial conflicts of interest policies in place. ${ }^{6} 1213$ Even when journals have editorial policies for conflicts of interest, studies estimate that only $12 \%$ of journals have published such policies and only $30 \%$ of policies had clear requirements for editor recusal. ${ }^{12}$ Such lack of standardisation could create a perception that editors fail to adhere to the very conflicts of interest requirements they have appropriately developed for authors.

As part of the Affordable Care Act the US Centers for Medicare and Medicaid Services (CMS) have made available all payments by pharmaceutical and medical device manufacturer to doctors and other clinicians publicly available through the Open Payments database. $^{29} 30$ We used this database to examine industry payments to journal editors at 52 influential US medical journals during 2014.

\section{Methods}

\section{Journal selection}

We identified 52 influential (ie, high impact factor for their specialty) clinical based medical journals based in the US (table 1). After a review of the Association of American Medical College 2014 Physician Data Source Book we selected the 20 most common physician specialties for inclusion-that is, US physician specialties with the largest number of active physicians. ${ }^{31}$ We added five additional specialties that we (as practicing clinicians) thought must be included because of their clinical and economic importance: infectious diseases, endocrinology, critical care medicine, rheumatology, and geriatrics. Because these journals have global impact, but encompass topics from across all specialties and disciplines, we included an additional category: high impact internationally influential US based general medicine journals.

After identifying the six journal categories for inclusion, we selected the most influential US based journals for each discipline in the following manner. Using online sources, including online journal websites, we identified three or four potential journals in each discipline with the highest impact factor in 2014-15. We excluded journals that primarily focused on basic science because Open Payments only collects information on payments to clinicians and thus it

Table 1 | List of journals, journal specialty, number of editors, editors eligible for Open Payments, ${ }^{\star}+$ and industry payments $¥$ reported in Open Payment database, 2014

\begin{tabular}{|c|c|c|c|c|c|c|c|c|}
\hline \multirow[b]{2}{*}{ Journal } & \multirow[b]{2}{*}{ Journal specialty } & \multirow[b]{2}{*}{$\begin{array}{l}\text { No of } \\
\text { editors }\end{array}$} & \multirow{2}{*}{$\begin{array}{l}\text { Editors } \\
\text { eligible for } \\
\text { Open } \\
\text { Payments* }\end{array}$} & \multirow[b]{2}{*}{$\begin{array}{l}\text { Eligible editors } \\
\text { with general } \\
\text { payments >\$0 }\end{array}$} & \multicolumn{2}{|c|}{ General payments (\$) } & \multicolumn{2}{|c|}{ Research payments (\$) } \\
\hline & & & & & Mean (SD) & $\begin{array}{l}\text { Median } \\
\text { (interquartile } \\
\text { range) }\end{array}$ & Mean (SD) & $\begin{array}{l}\text { Median } \\
\text { (interquartile } \\
\text { range) }\end{array}$ \\
\hline All journals & NA & 988 & 713 & 361 & $\begin{array}{l}27564 \\
(410772)\end{array}$ & 0 & $37330(173495)$ & 0 \\
\hline $\begin{array}{l}\text { New England Journal } \\
\text { of Medicine }\end{array}$ & $\begin{array}{l}\text { High impact } \\
\text { general medicine }\end{array}$ & 26 & 20 & 2 & $129(513)$ & $0(0-0)$ & $0(0)$ & $0(0-0)$ \\
\hline $\begin{array}{l}\text { Journal of the } \\
\text { American Medical } \\
\text { Association (JAMA) }\end{array}$ & $\begin{array}{l}\text { High impact } \\
\text { general medicine }\end{array}$ & 33 & 31 & 12 & $6331(18084)$ & $0(0-50)$ & $84516(325572)$ & $0(0-0)$ \\
\hline $\begin{array}{l}\text { Annals of Internal } \\
\text { Medicine }\end{array}$ & $\begin{array}{l}\text { General internal } \\
\text { medicine }\end{array}$ & 23 & 19 & 4 & $53(183)$ & $0(0-0)$ & $226(984)$ & $0(0-0)$ \\
\hline $\begin{array}{l}\text { JAMA Internal Med- } \\
\text { icine }\end{array}$ & $\begin{array}{l}\text { General internal } \\
\text { medicine }\end{array}$ & 6 & 6 & 3 & $59(87)$ & $9(0-106)$ & $122712(300582)$ & $0(0-0)$ \\
\hline $\begin{array}{l}\text { Annals of Family } \\
\text { Medicine }\end{array}$ & Family medicine & 12 & 10 & 2 & $1376(4342)$ & $0(0-0)$ & $27517(87015)$ & $0(0-0)$ \\
\hline $\begin{array}{l}\text { American Family } \\
\text { Physician }\end{array}$ & Family medicine & 11 & 10 & 2 & $3(7)$ & $0(0-0)$ & $0(0)$ & $0(0-0)$ \\
\hline Pediatrics & Paediatrics & 9 & 9 & 2 & 572 (1134) & $0(0-0)$ & $0(0)$ & $0(0-0)$ \\
\hline JAMA Pediatrics & Paediatrics & 4 & 4 & 1 & $6(11)$ & $0(0-6)$ & $0(0)$ & $0(0-0)$ \\
\hline $\begin{array}{l}\text { Obstetrics and } \\
\text { Gynecology }\end{array}$ & $\begin{array}{l}\text { Obstetrics and } \\
\text { gynaecology }\end{array}$ & 3 & 3 & 0 & $0(0)$ & $0(0-0)$ & $0(0)$ & $0(0-0)$ \\
\hline $\begin{array}{l}\text { American Journal } \\
\text { of Obstetrics and } \\
\text { Gynecology }\end{array}$ & $\begin{array}{l}\text { Obstetrics and } \\
\text { gynaecology }\end{array}$ & 14 & 14 & 7 & 644 (2134) & $8(0-107)$ & $5591(20182)$ & $0(0-0)$ \\
\hline Anesthesiology & Anaesthesiology & 15 & 10 & 6 & 7622 (15 512) & $15(0-8290)$ & 3778 (10 172) & $0(0-284)$ \\
\hline Pain & Anaesthesiology & 81 & 11 & 6 & $14203(31094)$ & $520(0-4952)$ & 38582 (101958) & $0(0-0)$ \\
\hline JAMA Psychiatry & Psychiatry & 2 & 2 & 7 & $3956(5595)$ & 3956 & $900(1273)$ & 900 \\
\hline $\begin{array}{l}\text { American Journal of } \\
\text { Psychiatry }\end{array}$ & Psychiatry & 24 & 21 & 1 & $4410(7770)$ & $0(0-4877)$ & $11017(26871)$ & $0(0-325)$ \\
\hline $\begin{array}{l}\text { Annals of Emergency } \\
\text { Medicine }\end{array}$ & $\begin{array}{l}\text { Emergency } \\
\text { medicine }\end{array}$ & 31 & 30 & 10 & $5230(23558)$ & $0(0-18)$ & 3528 (13 161) & $0(0-0)$ \\
\hline $\begin{array}{l}\text { American Journal of } \\
\text { Emergency Medicine }\end{array}$ & $\begin{array}{l}\text { Emergency } \\
\text { medicine }\end{array}$ & 1 & 1 & 0 & 0 (NA) & $0(0-0)$ & $0(N A)$ & $0(0-0)$ \\
\hline
\end{tabular}


Table 1 | List of journals, journal specialty, number of editors, editors eligible for Open Payments, ${ }^{\star}+$ and industry payments‡ reported in 0 pen Payment database, 2014 (Continued)

\begin{tabular}{|c|c|c|c|c|c|c|c|c|}
\hline \multirow[b]{2}{*}{ Journal } & \multirow[b]{2}{*}{ Journal specialty } & \multirow[b]{2}{*}{$\begin{array}{l}\text { No of } \\
\text { editors }\end{array}$} & \multirow{2}{*}{$\begin{array}{l}\text { Editors } \\
\text { eligible for } \\
\text { Open } \\
\text { Payments* }\end{array}$} & \multirow[b]{2}{*}{$\begin{array}{l}\text { Eligible editors } \\
\text { with general } \\
\text { payments >\$0 }\end{array}$} & \multicolumn{2}{|c|}{ General payments (\$) } & \multicolumn{2}{|c|}{ Research payments (\$) } \\
\hline & & & & & Mean (SD) & $\begin{array}{l}\text { Median } \\
\text { (interquartile } \\
\text { range) }\end{array}$ & Mean (SD) & $\begin{array}{l}\text { Median } \\
\text { (interquartile } \\
\text { range) }\end{array}$ \\
\hline Radiology & Radiology & 19 & 10 & 4 & $11559(24288)$ & $0(0-9794)$ & 94920 (297 930) & $0(0-0)$ \\
\hline $\begin{array}{l}\text { American Journal of } \\
\text { Roentgenology }\end{array}$ & Radiology & 32 & 32 & 9 & $2917(12943)$ & $0(0-38)$ & $0(0)$ & $0(0-0)$ \\
\hline Annals of Surgery & Surgery & 6 & 5 & 1 & $384(860)$ & $0(0-0)$ & $2369(5298)$ & $0(0-0)$ \\
\hline JAMA Surgery & Surgery & 4 & 4 & 4 & $73(50)$ & $70(32-110)$ & $57244(77340)$ & $\begin{array}{l}32654 \\
(0-89898)\end{array}$ \\
\hline $\begin{array}{l}\text { Journal of the } \\
\text { American College of } \\
\text { Cardiology }\end{array}$ & Cardiology & 35 & 24 & 19 & $\begin{array}{l}475072 \\
(2237949)\end{array}$ & $7438(276-22096)$ & 119407 (286 546) & $\begin{array}{l}11974 \\
(0-67712)\end{array}$ \\
\hline Circulation & Cardiology & 29 & 28 & 20 & $11685(24001)$ & $164(0-5596)$ & $75396(235757)$ & $0(0-0)$ \\
\hline $\begin{array}{l}\text { Journal of Bone and } \\
\text { Joint Surgery }\end{array}$ & Orthopaedics & 34 & 21 & 16 & $\begin{array}{l}101668 \\
(280647)\end{array}$ & $253(20-51250)$ & $15575(56881)$ & $0(0-0)$ \\
\hline $\begin{array}{l}\text { American Journal of } \\
\text { Sports Medicine }\end{array}$ & Orthopaedics & 2 & 2 & 1 & $8(11)$ & $8(4-11)$ & $0(0)$ & $0(0-0)$ \\
\hline $\begin{array}{l}\text { American Journal of } \\
\text { Ophthalmology }\end{array}$ & Ophthalmology & 22 & 18 & 13 & $8942(23461)$ & $370(38-6889)$ & $6332(14568)$ & $0(0-0)$ \\
\hline Ophthalmology & Ophthalmology & 35 & 26 & 10 & $5811(23264)$ & $0(0-2014)$ & $0(0)$ & $0(0-0)$ \\
\hline $\begin{array}{l}\text { Journal of the National } \\
\text { Cancer Institute }\end{array}$ & Oncology & 85 & 59 & 30 & $5154(13576)$ & $0(0-519)$ & $76223(323500)$ & $0(0-0)$ \\
\hline $\begin{array}{l}\text { Journal of Clinical } \\
\text { Oncology }\end{array}$ & Oncology & 19 & 8 & 5 & $5957(9474)$ & $228(0-8752)$ & 160304 (307 252) & $\begin{array}{l}31999 \\
(0-144198)\end{array}$ \\
\hline $\begin{array}{l}\text { American Journal of } \\
\text { Pathology }\end{array}$ & Pathology & 27 & 13 & 2 & $12(28)$ & $0(0-0)$ & $0(0)$ & $0(0-0)$ \\
\hline $\begin{array}{l}\text { American Journal of } \\
\text { Surgical Pathology }\end{array}$ & Pathology & 1 & 1 & 0 & $0(N A)$ & $0(0-0)$ & $0(N A)$ & $0(0-0)$ \\
\hline Gastroenterology & Gastroenterology & 21 & 16 & 6 & $18630(45033)$ & $0(0-8527)$ & $3203(8011)$ & $0(0-316)$ \\
\hline $\begin{array}{l}\text { American Journal of } \\
\text { Gastroenterology }\end{array}$ & Gastroenterology & 34 & 26 & 20 & 24090 (47 197) & $5863(22-23941)$ & $54454(112693)$ & $0(0-48189)$ \\
\hline Annals of Neurology & Neurology & 10 & 10 & 5 & $1313(2904)$ & $5(0-34)$ & $10250(32413)$ & $0(0-0)$ \\
\hline JAMA Neurology & Neurology & 9 & 9 & 6 & $3546(6913)$ & $51(0-4716)$ & 73708 (201961) & $0(0-11100)$ \\
\hline $\begin{array}{l}\text { Journal of the } \\
\text { American Academy of } \\
\text { Dermatology }\end{array}$ & Dermatology & 9 & 8 & 6 & $15278(37820)$ & $176(18-6494)$ & $9793(26344)$ & $0(0-856)$ \\
\hline JAMA Dermatology & Dermatology & 2 & 2 & 1 & $1544(2184)$ & $1544(772-2316)$ & $0(0)$ & $0(0-0)$ \\
\hline Journal of Urology & Urology & 5 & 4 & 4 & $6795(13066)$ & $380(75-7099)$ & $0(0)$ & $0(0-0)$ \\
\hline The Prostate & Urology & 3 & 1 & 1 & $490(N A)$ & $490(490-490)$ & $0(\mathrm{NA})$ & $0(0-0)$ \\
\hline $\begin{array}{l}\text { Journal of the } \\
\text { American Society of } \\
\text { Nephrology }\end{array}$ & Nephrology & 17 & 14 & 12 & $7499(11412)$ & $1136(148-11396)$ & $8876(25704)$ & $0(0-17)$ \\
\hline Kidney International & Nephrology & 11 & 5 & 3 & $449(890)$ & $78(0-131)$ & $11273(25208)$ & $0(0-0)$ \\
\hline $\begin{array}{l}\text { Otolaryngology Head } \\
\text { and Neck }\end{array}$ & Otolaryngology & 19 & 18 & 16 & $891(1974)$ & $118(26-428)$ & $0(0)$ & $0(0-0)$ \\
\hline Head and Neck & Otolaryngology & 22 & 14 & 11 & $5703(13066)$ & $1390(94-4626)$ & $40586(101136)$ & $0(0-0)$ \\
\hline $\begin{array}{l}\text { Clinical Infectious } \\
\text { Diseases }\end{array}$ & $\begin{array}{l}\text { Infectious dis- } \\
\text { eases }\end{array}$ & 14 & 14 & 8 & $6458(14759)$ & $51(0-1162)$ & $3213(8144)$ & $0(0-0)$ \\
\hline $\begin{array}{l}\text { Journal of Infectious } \\
\text { Diseases }\end{array}$ & $\begin{array}{l}\text { Infectious dis- } \\
\text { eases }\end{array}$ & 14 & 13 & 5 & $\begin{array}{l}44140 \\
(141273)\end{array}$ & $0(0-3645)$ & 17526 (39 389) & $0(0-1625)$ \\
\hline Diabetes Care & Endocrinology & 18 & 14 & 9 & $\begin{array}{l}96688 \\
(154229)\end{array}$ & $19618(0-128676)$ & $212426(530654)$ & $\begin{array}{l}9972 \\
(0-98844)\end{array}$ \\
\hline Diabetes & Endocrinology & 17 & 10 & 7 & $17306(28005)$ & $2773(9-21296)$ & $5275(15526)$ & $0(0-1053)$ \\
\hline $\begin{array}{l}\text { American Journal } \\
\text { for Respirology and } \\
\text { Critical Care Medicine }\end{array}$ & Critical care & 31 & 18 & 11 & $18307(48615)$ & $36(0-11950)$ & $81026(186800)$ & $0(0-16846)$ \\
\hline Chest & Critical care & 16 & 13 & 8 & 7101 (16348) & $88(0-1426)$ & $14784(53306)$ & $0(0-0)$ \\
\hline $\begin{array}{l}\text { Current Opinion in } \\
\text { Rheumatology }\end{array}$ & Rheumatology & 1 & 1 & 1 & $6890(\mathrm{NA})$ & $6890(6890-6890)$ & $0(N A)$ & $0(0-0)$ \\
\hline $\begin{array}{l}\text { Arthritis and } \\
\text { Rheumatology }\end{array}$ & Rheumatology & 35 & 26 & 16 & $26266(73037)$ & $386(0-15319)$ & $68323(129522)$ & $0(0-27558)$ \\
\hline $\begin{array}{l}\text { Journal for the } \\
\text { Association of } \\
\text { Geriatrics Society }\end{array}$ & Geriatrics & 18 & 17 & 4 & $1216(3043)$ & $0(0-0)$ & $27563(60678)$ & $0(0-0)$ \\
\hline $\begin{array}{l}\text { Journal of Gerontology } \\
\text { (Series A) }\end{array}$ & Geriatrics & 20 & 10 & 4 & $1830(3628)$ & $0(0-833)$ & $2065(6203)$ & $0(0-0)$ \\
\hline
\end{tabular}

$\mathrm{NA}=$ not applicable.

*A "physician" as defined by Open Payments; ie, doctors of medicine and osteopathy, dentists, podiatrists, optometrists, and chiropractors.

tColumns may not add to total of all journals, as data were adjusted to account for two editors who were eligible for Open Payments who each served on two journals.

¥All values rounded to the nearest \$. 
would not be useful to include editors at journals that were primarily focused on the basic sciences. As Open Payments only reports payments to clinicians residing in the US, we then excluded journals based outside the US. $^{32}$ Finally, we excluded ultra specialised journals that may have fit all other criteria but were extremely narrow in clinical focus (eg, a journal that focused on retinal surgery) because such niche journals inherently have more limited readership and reach. Our final list included two journals from each of 26 different medical disciplines (52 journals in total).

\section{Editor selection}

Two authors (JJL and PC) identified all editors listed in online mastheads of the 52 selected journals during May 2016, including editors in chief; senior, managing, deputy, or executive editors; and associate editors (henceforth referred to simply as editors). We purposefully did not include at large editorial board members. We assumed that editors at or above the associate editor level made important editorial decisions about manuscript publication. Because Open Payments only collects information on payments to physicians, we excluded non-physician editors. We defined "physician" using the same criteria as Open Payments (ie, doctors of medicine and osteopathy, but also dentists, podiatrists, optometrists, and chiropractors); thus, from a practical standpoint a journal editor who was a dentist or podiatrist would be included in our editor database. ${ }^{33}$ For all editors, we reviewed their name, academic affiliation, and location of practice using available online resources and information included in the journals' mastheads; we subsequently excluded editors who were based outside of the US since Open Payments only collects payments to US based clinicians.

\section{Editors in chief survey}

Recognising that journal mastheads may be vague, out of date, or unclear, we offered each journal's editor in chief an opportunity to review our list of editors. Specifically, we contacted each journal editor in chief by email and requested that they review an attached editor list for their journal and to make additions or deletions where appropriate (see supplementary appendices 1 and 2). We included a link to an online survey that asked editors in chief to provide information about their journal's editorial conflicts of interest policy (see supplementary appendix 3). Specifically, we asked editors whether the journal had an editorial conflicts of interest policy, whether editors must disclose conflicts of interest, and who adjudicates conflicts when identified. Editors were also asked their opinion on how well their journal handled editorial conflicts of interests (using a 1-5 Likert-like scale, 1 indicating "not at all satisfied," 5 indicating "extremely satisfied"). Our survey questions were derived and modified from previous studies that evaluated editorial conflicts of interest policies. ${ }^{12}$ Editors in chiefs were emailed between June and August 2016; those who did not respond within two weeks received a second email.

\section{Review of journal websites}

To examine whether editorial conflicts of interest policies and disclosures were publicly accessible, we supplemented our editors in chief survey by searching each journal's website in April 2017. Each of three study authors (JJL, PC, and ASD) was allocated five minutes for each journal (timed with a smartphone). Each author reviewed approximately 20 journals, with 10 reviewed in duplicate to assess inter-rater reliability. We limited our website review to five minutes for each journal under the rationale that journal conflicts of interest policies should be easily accessible if they are to be effective at promoting transparency.

\section{Open payments data extraction}

After editors were identified, we used Open Payments (www.cms.gov/openpayments/) to identify all payments made to eligible physicians in 2014. 323435 Briefly, the Affordable Care Act requires all pharmaceutical and medical device manufacturers and group purchasing organisations to report all payments to physicians to CMS. All payments must be reported, across a broad range of categories, such as food and beverage, royalties, honorariums, consulting fees, travel, and entertainment. Specific examples include consultancy payments for expertise provided by a physician; honorariums for short duration activities, such as advice on improvements to a medical device; and payment for physician attendance at a recreational, sporting, or cultural events. ${ }^{35} \mathrm{CMS}$ also collects data on research payments, which include direct payments for research activities (eg, coordinating patient enrolment in a study, study related tests). ${ }^{35}$

For each editor we identified payments by searching the database using his or her first and last name. In cases of ambiguity (most often because of common names that produced multiple matches), we conducted further matching by medical specialty of the physician and city of practice.

For each individual we extracted the value of two categories of payments as defined by CMS: general payments (eg, consulting fees, speaker's bureaus, reimbursement for meals and travel) and total research payments (eg, coordinating patient enrolment in a study). Our primary focus was on general payments because such payments would typically be deposited directly into personal bank accounts. We extracted data in May 2016 using the most recent physician payment data that were available through Open Payments at that time (payments for 2014). We updated our data in July-September 2016 to reflect any changes recorded in Open Payments.

\section{Descriptive statistics}

We calculated the mean and median general and research payments to editors at each of the 52 journals and then collapsed the 52 journals into 26 specialty disciplines. For each specialty we examined general and research payments. We examined the percentage of editors in each specialty receiving general payments exceeding specified thresholds (eg, \$25000). All 
analyses were conducted using Microsoft Excel and R version 3.0.2.

\section{Patient involvement}

No patients were involved in setting the research question or the outcome measures, nor were they involved in developing plans for design or implementation of the study. No patients were asked to advise on interpretation or writing up of results. There are no plans to disseminate the results of the research to study participants or the relevant patient community.

\section{Results}

Approximately $72.1 \%$ of editors (713/988) at our 52 journals were eligible for inclusion in Open Payments (table 1). Of eligible editors, 50.6\% (361/713) received general payments in 2014 and 19.5\% (139/713) received research payments. For the 713 editors, the median general payment was $\$ 11$ (interquartile range $\$ 0-2923)$ and the median payment for research was $\$ 0$ (\$0-0).

Table 1 shows that the highest median general payments received by journal editors were from endocrinology (\$7207, interquartile range \$0-85 816), cardiology (\$2664, \$0-12912), gastroenterology (\$696, \$0-20 002), rheumatology (\$515, \$0-14 280), and urology (\$480, \$90-669). For high impact general medical journals, median payments were $\$ 0$ (\$0-14). The five largest individual physician general payments to editors came from four specialty journals: cardiology (\$10 981 153), orthopaedics (\$1 264234 and \$325 860), endocrinology (\$554162), and rheumatology (\$355 923).

We also examined the percentage of editors, by specialty, who received general payments in excess of certain specified thresholds ( $\geq \$ 0, \$ 10000, \$ 25000$, $\$ 50000$, and $\$ 100000$ ) (see supplementary appendix figures 5-9). Even beyond these thresholds, there were notable outliers-for example, two editors received general payments of greater than $\$ 1 \mathrm{~m}$ in 2014 (\$1 263234 and \$10 981 153) (table 2).

The response rate to our editors in chief survey was $15 / 52(28.8 \%)$. Figure 1 summarises the results of the survey.

In our review of journal websites, we found conflicts of interest policies for $32.7 \%$ (17/52) of journals. For an additional $5.8 \%$ of journals (3/52) the existence of a conflicts of interest policy was strongly inferred by website information but we could not find the actual policy. Agreement between reviewers was excellent $(\kappa=0.74)$. Posted policies varied substantially for detail of information provided. Of the 20 journals with posted or inferred policies, the implication was that all personal and industry related editorial conflicts of interest were self disclosed. Formal recusal processes were mentioned by 15 of the 20 journals with policies. The websites of several journals (Journal of the American Academy of Dermatology, American Journal of Sports Medicine, Annals of Emergency Medicine, Journal of Urology) stated that editors must disclose conflicts of interest with no specific mention of how such conflicts of interest are handled. Annals of Emergency Medicine published very detailed

Table 2 | General payments* to journal editors in 2014 , by journal specialty

\begin{tabular}{|c|c|c|c|c|c|}
\hline \multirow{2}{*}{ Journal specialty } & \multicolumn{2}{|c|}{ Eligible editors } & \multirow[b]{2}{*}{ Mean (SD) payment (\$) } & \multirow{2}{*}{$\begin{array}{l}\text { Median } \\
\text { (interquartile range }\end{array}$} & \multirow{2}{*}{$\begin{array}{l}\text { Highest payment to } \\
\text { individual editor (\$) }\end{array}$} \\
\hline & No & No with any payment (>0\$) & & & \\
\hline High impact general medicine & 51 & 14 & $3899(14341)$ & $0(0-14)$ & 78617 \\
\hline General internal medicine & 25 & 7 & $54(163)$ & $0(0-18)$ & 795 \\
\hline Family medicine & 20 & 4 & $690(3,070)$ & $0(0-0)$ & 13733 \\
\hline Paediatrics & 13 & 3 & $397(965)$ & $0(0-0)$ & 2600 \\
\hline Obstetrics and gynaecology & 17 & 7 & $531(1940)$ & $0(0-50)$ & 8038 \\
\hline Anaesthesiology & 21 & 12 & $8683(21727)$ & $0(0-4469)$ & 97529 \\
\hline Psychiatry & 23 & 9 & $4371(7505)$ & $0(0-6394)$ & 20600 \\
\hline Emergency medicine & 31 & 10 & $5061(23181)$ & $0(0-16)$ & 127922 \\
\hline Radiology & 41 & 13 & $4974(16433)$ & $0(0-178)$ & 77366 \\
\hline Surgery & 9 & 5 & $246(630)$ & $27(0-105)$ & 1922 \\
\hline Cardiology & 52 & 38 & $225556(1520990)$ & $2664(0-12912)$ & 10981153 \\
\hline Orthopaedics & 23 & 17 & $92828(269185)$ & $121(8-29344)$ & 1263234 \\
\hline Ophthalmology & 44 & 23 & $7092(23124)$ & $115(0-4392)$ & 119331 \\
\hline Oncology & 67 & 35 & $5249(13098)$ & $11(0-811)$ & 57282 \\
\hline Pathology & 14 & 2 & $11(27)$ & $0(0-0)$ & 80 \\
\hline Gastroenterology & 42 & 26 & $22010(45906)$ & $696(0-20002)$ & 214053 \\
\hline Neurology & 19 & 11 & $2370(5174)$ & $11(0-2346)$ & 20887 \\
\hline Dermatology & 10 & 7 & $12531(33861)$ & $176(6-5541)$ & 108590 \\
\hline Urology & 5 & 5 & $5534(11661)$ & $490(90-669)$ & 26389 \\
\hline Nephrology & 19 & 15 & $5644(10218)$ & $359(86-6086)$ & 36479 \\
\hline Otolaryngology & 32 & 27 & $2996(8923)$ & $172(42-2204)$ & 50203 \\
\hline Infectious diseases & 27 & 14 & $24601(98430)$ & $0(0-2522)$ & 512421 \\
\hline Endocrinology & 24 & 16 & $63612(123894)$ & $7207(0-85816)$ & 554162 \\
\hline Critical care & 31 & 19 & $13608(38442)$ & $55(0-9093)$ & 207414 \\
\hline Rheumatology & 27 & 17 & $25548(71716)$ & $515(0-14280)$ & 355923 \\
\hline Geriatrics & 27 & 8 & $1443(3216)$ & $0(0-30)$ & 11409 \\
\hline
\end{tabular}




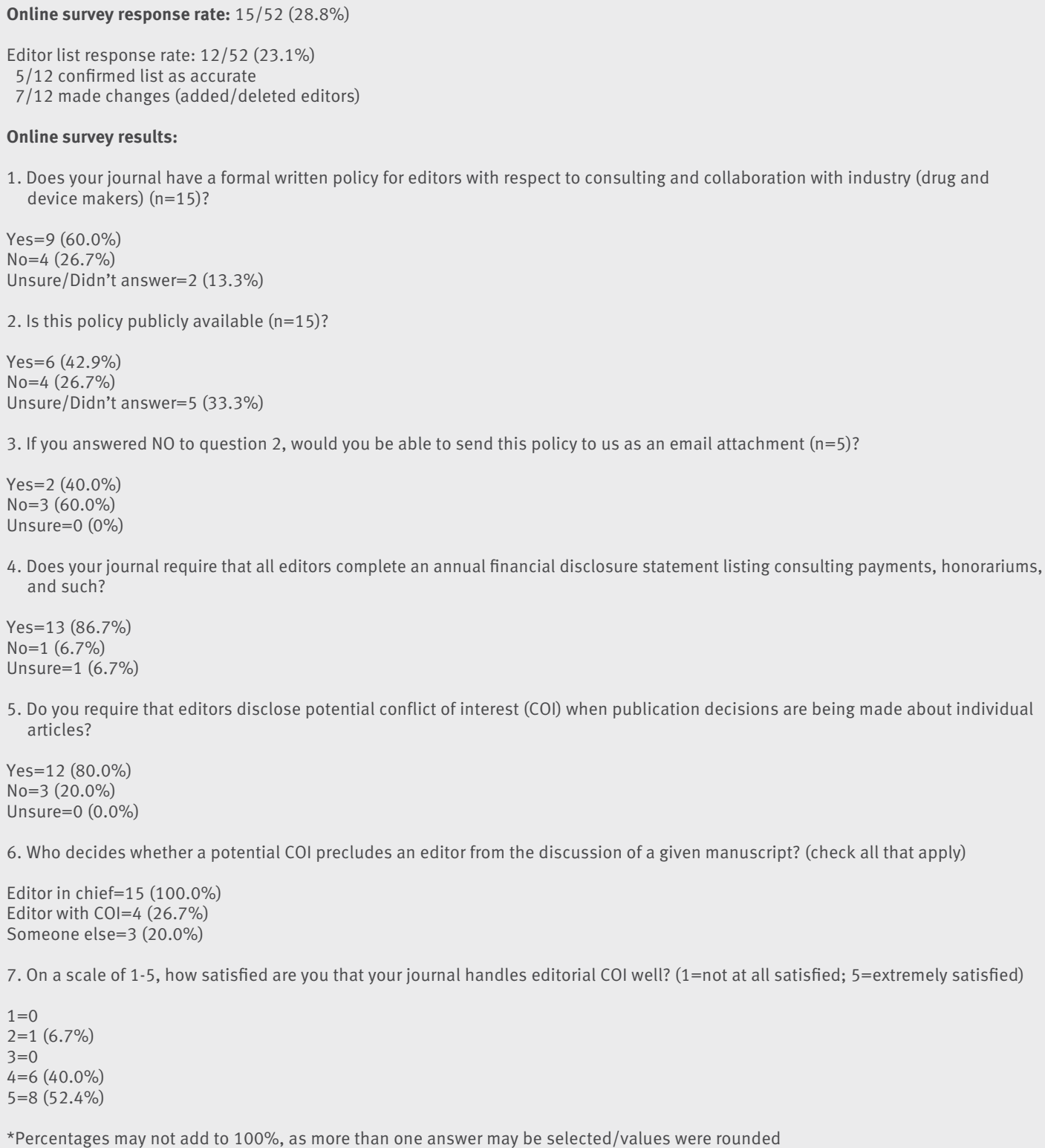

Fig $1 \mid$ Results of survey emailed to editors in chief of 52 journals

information about editor relations with industry, and the Journal of Urology provided an email address to request further information. We noted that one journal (Anesthesiology) handled transparency of editor conflicts of interest particularly well, with an accessible policy as well as detailed information on specific editor relations with industry.

\section{Discussion}

We used information from the CMS Open Payments database to examine financial payments from industry to US editors of 52 prestigious medical journals drawn from 26 specialties in 2014. We found that 50.9\% of editors received at least some general payments from industry, and these payments were often large.

It is important to consider our findings of payments to editors in the context of the existing literature on industry payments to physicians. Previous studies of industry payments have typically focused on general populations of physicians, have not used Open Payments, and have not specifically focused on editors. ${ }^{36-39}$ Nevertheless, review of the existing literature is informative. Two separate analyses of Open Payments data reported overall median payments between $\$ 100$ and $\$ 201$ for all physicians, which is higher than our finding of median general payments to editors of $\$ 11 .^{3637}$ In addition, one of the analyses reported overall mean general payments of $\$ 1407$ to all physicians, compared with our finding that editors received mean general payments of $\$ 27941 .{ }^{37}$ Several studies focusing on orthopaedics found median general payments ranging from $\$ 38-\$ 420$ compared with our finding of payments to editors of $\$ 121$. $^{4041}$ Similarly, other studies reported median general 
payments ranging from $\$ 175-\$ 1851$ for physicians specialising in cardiovascular diseases, compared with our findings of $\$ 2664 .{ }^{363742}$

It is also important to compare our findings with information directly available from Open Payments, which reports all mean and median payments of a given specialty annually. ${ }^{35}$ Generally speaking, median general payments to editors of a specific specialty were higher than median general payments of all physicians in the specialty as reported by Open Payments. For example, we found median payments to cardiology journal editors of \$2664 compared with Open Paymentsreported median payments of $\$ 582$ to all cardiologists. Similarly, median payments to gastroenterology editors were $\$ 696$ versus $\$ 475$ reported by Open Payments for all gastroenterologists, and median payments to endocrinology editors were $\$ 7207$ versus $\$ 758$ reported by Open Payments for all endocrinologists.

We found differences in payment to editors between specialties that might have been expected. Payments were higher for specialties that rely on costly devices (cardiology, orthopaedics) and specialties where there has been recent innovation in development of drugs used to treat chronic diseases over long periods (endocrinology). ${ }^{434}$ Surprisingly, payments were not high for other specialties (eg, oncology) with major innovation and where previous research has found physician-industry relations common. ${ }^{45}$

Our finding that editors of high impact journals (in specialties such as cardiology, gastroenterology, and endocrinology) receive larger payments than the typical practicing physician of the same specialty should raise questions. It is well recognised that pharmaceutical and medical device makers target physician "thought leaders" for lucrative consulting and advisory roles. ${ }^{38} 39$ 46-51 The rationale for such a strategy is that these leaders can influence both their physician peers and trainees to boost sales of products. Our finding suggests that, not surprisingly, editors at influential journals are attractive to industry; indeed, the same traits that make an individual attractive to an influential journal as a candidate for an editorial role would likely make that individual attractive to industry. At the same time, it is important to acknowledge that we do not know if editorial relations influence publication decisions. In the best case, the answer would be a categorical "no." That said, even the appearance of conflicts of interest can severely damage the fragile public trust in the medical research enterprise..$^{52}$ Editors have an important influence and responsibility for ensuring the integrity of medical research. ${ }^{45}$ Editorships at high impact journals are sought after positions, and editors set the tone for the rest of the academic profession.

Despite the recommendation from professional associations such as the ICMJE, WAME, and COPE regarding editorial conflicts of interest policies, our finding that only one third of journals have readily accessible editorial conflicts of interest policies is consistent with previous studies. ${ }^{12} 1526-2853$ We found that even when journals posted editorial conflicts of interest policies on their websites, the degree of detail differed considerably, consistent with previous studies in this area. ${ }^{6712}$ We would contend that policies, although necessary, are not sufficient, and there seems to be important shortcomings in the implementation and enforcement of these policies at many journals.

The organisation of the 52 journals included in our study varied tremendously. The number of editors at included journals ranged from 1 to 85, and job titles were highly variable. There was also variability in the time commitment required by editors, and in compensation. At some journals, editors are reimbursed well for their time whereas at others work is basically performed on a volunteer basis. Similarly, we found noticeable variation in the rigor with which editorial conflicts of interest policies were implemented. Given the variability in journal organisation and oversight it is not surprising that payments varied markedly, even between journals within the same specialty. It is also worthwhile wondering whether the 52 journals included in our study are representative of all journals with respect to editor-industry payments. We would posit that our highly influential journals are well resourced and prestigious and may well represent the "best case." Further study is needed to expand our work to a larger sample of journals.

To address potential editor conflicts of interest, journals typically have recusal processes that exclude editors from review of manuscripts where the editor has a conflict; we found that three quarters of journals reported having a recusal process on their website. However, for all journals, potential editorial conflicts of interest are only identified by editor self report, and previous studies have shown self report of conflicts of interest to have considerable shortcomings. ${ }^{53-57}$ While editors may not believe that financial payments from industry influence their judgments, there is evidence to suggest that all individuals are subject to subconscious bias from many kinds of influences that are much more subtle than money, the impact of which may be even more difficult to ascertain and self report. ${ }^{1315}$

Finally, it is important to consider the case of physician entrepreneurship as a reason for exceptional payments. An internet search of one editor who received general payments of $\$ 10981153$ in 2014 revealed that this individual founded a private company that was subsequently sold to an international medical device corporation in 2012. Many of the key publications for this device were published in the same journal where the company physician founder served as an editor. While we would never question the value of physician entrepreneurship or whether physician inventors should be compensated well for their inventions, there are important concerns about potential conflicts of interest, and we wonder whether such entrepreneurs should be allowed to serve as editors. ${ }^{58}$

\section{Strengths and limitations of this study}

Open Payments, made available by the Affordable Care Act, has provided a valuable source of data to improve research into clinician-industry relations. ${ }^{29-35}$ Previous studies of financial relations have relied 
on either physician self report or smaller databases made available by specific companies or states. ${ }^{5} 3839$ Open payments is unique because of its reach-all payments from pharmaceutical and medical device manufacturers to all US clinicians. ${ }^{30}$ Because Open Payments collects data directly from companies, the database circumvents well recognised problems inherent in obtaining data from physician self reports, including faulty memory and selective recall. ${ }^{5}$ 51-55 Studies have shown that journals are more likely to publish reports from members of their own editorial membership, ${ }^{9}$ although others have shown the opposite. ${ }^{13}$ Thus, our study expands substantially on previous research by providing far more accurate data on the percentage of editors receiving payments and the quantity of those payments.

We acknowledge several limitations. Firstly, there is considerable heterogeneity in how editorial decisions were made across journals. Our intent was to focus on those with an active role in the editorial process; we intentionally omitted individuals such as editorial board members who do not have ultimate control of publication decisions. We also gave all editors in chief a chance to review our editorial lists and received few modifications. Secondly, while we selected journals in a rigorous and transparent manner, we acknowledge that there is likely no method to select journals for inclusion that would satisfy everyone. In addition, while two of our journals (American Family Physician and Current Opinion in Rheumatology) do not publish original research, they meet our other inclusion criteria. Moreover, journals focusing on clinical audiences can be influential, and editorial conflicts at such journals are relevant. Thirdly, we obtained our list of editors in 2016 but examined payments in 2014; we would contend that the mismatch in timing is both unavoidable and largely immaterial. Even if relations were terminated within the interceding timeframe, the potential impact of payments (ie, favourable disposition towards a particular drug or device) is likely to linger. The standardised ICJME disclosure form recommends reporting financial relations within the previous 36 months; therefore, we thought it reasonable to extract 2014 payment data using 2016 editorial mastheads, as any purported influence from industry would fall within this period. Fourthly, Open Payments is currently limited to payments to pharmaceutical and medical device industry; editors who have relations with, for example, electronic health record vendors are not captured. Finally, data are limited to payments to independently licensed clinicians as defined by Open Payments; nurse practitioners, pharmacists, and those with $\mathrm{PhD}$ degrees are not captured.

\section{Conclusions}

We found that industry payments to journal editors are common and can be substantial. Moreover, many journals lack clear and transparent editorial conflicts of interest policies and disclosures. Given our findings, we would suggest that journals take several steps. Firstly, we would strongly argue that all journals should develop and implement a transparent, publicly accessible editorial conflicts of interest policy. Secondly, editors in chief should consider excluding those with considerable industry relations from editorial positions. While such a stance could be considered drastic, editors play a crucial role in research integrity; even an appearance of conflict can serve to undermine the clinical research enterprise.

In summary, we found that a substantial percentage of journal editors received personal payments from industry and these payments were often large. Journal editors should reconsider their conflict of interest policies and the impact that editor relations with industry may have on public trust in the research enterprise.

Contributors: All the authors made substantial contributions to the conception or design of the work, or the acquisition, analysis, or interpretation of the work; drafting the work or revising it critically for important intellectual content; gave final approval of the version to be published; and agree to be accountable for all aspects of the work in ensuring that questions related to the accuracy or integrity of any part of the work are appropriately investigated and resolved. JJL and PC are the guarantors.

Funding: PC is supported by a K24 award from NIAMS (AR062133). Competing interests: All authors have completed the ICMJE uniform disclosure form (available on request from the corresponding author) and declare: no support from any organisation for the submitted work; no financial relationships with any organisations that might have an interest in the submitted work in the previous three years, no other relationships or activities that could appear to have influenced the submitted work

Ethical approval: This study was approved by the Sinai Health System research ethics board.

Data sharing: No additional data available.

Transparency: The lead author (JJL) affirms that the manuscript is an honest, accurate, and transparent account of the study being reported; that no important aspects of the study have been omitted; and that any discrepancies from the study as planned (and, if relevant, registered) have been explained.

This is an Open Access article distributed in accordance with the Creative Commons Attribution Non Commercial (CC BY-NC 4.0) license, which permits others to distribute, remix, adapt, build upon this work non-commercially, and license their derivative works on different terms, provided the original work is properly cited and the use is noncommercial. See: http://creativecommons.org/licenses/by-nc/4.0/.

1 Bartley GB, Liesegang TJ. Just because it's published doesn't mean it's perfect: the continuing evolution of the peer review process. Ophthalmology 2015;122:1958-9. doi:10.1016/j. ophtha.2015.06.006

2 Ray JG. Judging the judges: the role of journal editors. OJM 2002;95:769-74. doi:10.1093/qjmed/95.12.769

3 Benson PJ. Eyes wide open: reader and author responsibility in understanding the limits of peer review. Ann R Coll Surg Engl 2015;97:487-9. doi:10.1308/rcsann.2015.0032

4 Ross JS, Hill KP, Egilman DS, Krumholz HM. Guest authorship and ghostwriting in publications related to rofecoxib: a case study of industry documents from rofecoxib litigation. JAMA 2008;299: 1800-12. doi:10.1001/jama.299.15.1800

5 Stelfox HT, Chua G, O'Rourke K, Detsky AS. Conflict of interest in the debate over calcium-channel antagonists. N Engl J Med 1998;338:101-6. doi:10.1056/NEJM199801083380206

6 Smith R. Medical journals are an extension of the marketing arm of pharmaceutical companies. PLoS Med 2005;2:e138. doi:10.1371/ journal.pmed.0020138

7 Smith E, Potvin MJ, Williams-Jones B. Accessibility and transparency of editor conflicts of interest policy instruments in medical journals. J Med Ethics 2012;38:679-84. doi:10.1136/ medethics-2012-100524

8 Davis RM, Mülner M. Editorial independence at medical journals owned by professional associations: a survey of editors. Sci Eng Ethics 2002;8:513-28. doi:10.1007/s11948-0020004-7

9 Janssen SJ, Bredenoord AL, Dhert W, de Kleuver M, Oner FC, Verlaan JJ. Potential conflicts of interest of editorial board members from five leading spine journals. PLoS One 2015;10:e0127362. 
10 Mehlman CT, Okike K, Bhandari M, Kocher MS. Potential financial conflict of interest among physician editorial board members of orthopaedic surgery. J Bone Joint Surg Am 2017;99:e19. doi:10.2106/JBJS.16.00227.

11 Luty J, Arokiadass SM, Easow JM, Anapreddy JR. Preferential publication of editorial board members in medical specialty journals. J Med Ethics 2009;35:200-2. doi:10.1136/ jme.2008.026740

12 Cooper RJ, Gupta M, Wilkes MS, Hoffman JR. Conflict of Interest Disclosure Policies and Practices in Peer-reviewed Biomedical Journals. J Gen Intern Med 2006;21:1248-52. doi:10.1111/j.15251497.2006.00598x

13 Bosch X, Pericas JM, Hernández C, Doti P. Financial, nonfinancial and editors' conflicts of interest in high-impact biomedical journals. Eur J Clin Invest 2013;43:660-7. doi:10.1111/eci.12090.

14 Mani J, Makarević J, Juengel E, et al. I publish in I edit?--Do editorial board members of urologic journals preferentially publish their own scientific work? PLoS One 2013;8:e83709. doi:10.1371/journal. pone.0083709

15 Haivas I, Schroter S, Waechter F, Smith R. Editors' declaration of their own conflicts of interest. CMAJ 2004;171:475-6. doi:10.1503/ cmaj.1031982

16 van Dijk D, Manor O, Carey LB. Publication metrics and success on the academic job market. Curr Biol 2014;24:R516-7. doi:10.1016/j. cub.2014.04.039

17 Rothenstein JM, Tomlinson G, Tannock IF, Detsky AS. Company stock prices before and after public announcements related to oncology drugs. J Natl Cancer Inst 2011;103:1507-12. doi:10.1093/jnci/ djr338

18 Overgaard CB, van den Broek RA, Kim JH, Detsky AS. Biotechnology stock prices before public announcements: evidence of insider trading? I Investig Med 2000;48:118-24

19 Sullivan GM. What to Do When Your Paper Is Rejected. / Grad Med Educ 2015;7:1-3. doi:10.4300/JGME-D-14-00686.1

20 Sklar DP. What can I believe? Peer review, innovation, and 90 years of academic medicine. Acad Med 2015;90:999-1000. doi:10.1097/ ACM.0000000000000789

21 Blum JA, Freeman K, Dart RC, Cooper RJ. Requirements and definitions in conflict of interest policies of medical journals. IAMA 2009;302:2230-4. doi:10.1001/jama.2009.1669

22 Drazen JM, de Leeuw PW, Laine C, et al. Toward more uniform conflic disclosures--the updated ICMJE conflict of interest reporting form. $N$ Engl/ Med 2010;363:188-9. doi:10.1056/NEJMe1006030

23 Fontanarosa PB, Flanagin A, DeAngelis CD. Implementation of the ICMJE form for reporting potential conflicts of interest. IAMA 2010;304:1496. doi:10.1001/jama.2010.1429

24 Callaway E. Open peer review finds more takers. Nature 2016;539:343. doi:10.1038/nature.2016.20969

25 Smith R. Opening up BMJ peer review. A beginning that should lead to complete transparency. BMJ 1999;318:4-5. doi:10.1136/ bmj.318.7175.4

26 International Committee of Medical Journal Editors. Recommendations. Conflicts of interest. http://www.icmje.org/ recommendations/browse/roles-and-responsibilities/authorresponsibilities-conflicts-of-interest.html. Last accessed May 1, 2017

27 World Association of Medical Editors. Conflict of interest in peerreviewed medical journals. http://www.wame.org/about/conflict-ofinterest-in-peer-reviewed-medical. Last accessed May 1, 2017.

28 International standards for editors - Committee on Publication Ethics (COPE). https://publicationethics.org/files/International\%20 standard editors for\%20website_11_Nov_2011.pdf Last accessed September 9, 2017.

29 Agrawal S, Brennan N, Budetti P. The Sunshine Act--effects on physicians. N Engl J Med 2013;368:2054-7. doi:10.1056/ NEJMp1303523

30 Rosenthal MB, Mello MM. Sunlight as disinfectant--new rules on disclosure of industry payments to physicians. N Engl J Med 2013:368:2052-4 doi:10.1056/NEIMp1305090

312014 Physician Specialty Data Book. Center for Workforce Studies. November 2014. Association of American Medical Colleges. https://www.aamc.org/download/473260/ data/2014physicianspecialtydatabook.pdf. Last accessed May 1, 2017.

32 Santhakumar S, Adashi EY. The Physician Payment Sunshine Act: testing the value of transparency. JAMA 2015;313:23-4. doi:10.1001/jama.2014.15472

33 Open Payments (Physician Payments Sunshine Act). Fact sheet for physicians. https://www.cms.gov/regulations-and-guidance/ legislation/national-physician-payment-transparency-program/ downloads/physician-fact-sheet.pdf. Last accessed May 1, 2017.

34 Kirschner NM, Sulmasy LS, Kesselheim AS. Health policy basics: the Physician Payment Sunshine Act and the Open Payments program. Ann Intern Med 2014:161:519-21. doi:10.7326/M14-1303

35 Open Payments Database CMS. Available at: https://www.cms.gov/ openpayments/ [Accessed May 2016].)
36 Tringale KR, Marshall D, Mackey TK, Connor M, Murphy JD, Hattangadi-Gluth JA. Types and Distribution of Payments From Industry to Physicians in 2015. JAMA 2017;317:1774-84. doi:10.1001/jama.2017.3091

37 Marshall DC, Jackson ME, Hattangadi-Gluth JA. Disclosure of Industry Payments to Physicians: An Epidemiologic Analysis of Early Data From the Open Payments Program. Mayo Clin Proc 2016;91:84-96. doi:10.1016/j.mayocp.2015.10.016.

38 Fleischman W, Agrawal S, King M, et al. Association between payments from manufacturers of pharmaceuticals to physicians and regional prescribing: cross sectional ecological study. BM/ 2016;354:i4189. doi:10.1136/bmj.i4189

39 Hockenberry JM, Weigel P, Auerbach A, Cram P. Financial payments by orthopedic device makers to orthopedic surgeons. Arch Intern Med 2011;171:1759-65. doi:10.1001/archinternmed.2011.454

40 lyer S, Derman P, Sandhu HS. Orthopaedics and the Physician Payments Sunshine Act: An Examination of Payments to U.S Orthopaedic Surgeons in the Open Payments Database. J Bone Joint Surg Am 2016;98:e18.

41 Samuel AM, Webb ML, Lukasiewicz AM, et al. Orthopaedic Surgeons Receive the Most Industry Payments to Physicians but Large Disparities are Seen in Sunshine Act Data. Clin Orthop Relat Res 2015:473:3297-306 doi:10.1007/s11999-015-4413-8

42 Parreco J, Donath E, Kozol R, Faber C. Comparing industry compensation of cardiothoracic surgeons and interventional cardiologists. / Surg Res 2017:208:51-9.

43 Thomas M. Interventional cardiology and the medical devices industry: is there a conflict of interest? Heart 2007;93:1351-2. doi:10.1136/hrt.2007.123133

44 Norris SL, Holmer HK, Ogden LA, Burda BU, Fu R. Conflicts of interest among authors of clinical practice guidelines for glycemic control in type 2 diabetes mellitus. PLoS One 2013;8:e75284. doi:10.1371/ ournal.pone.0075284

45 Roseman M, Milette K, Bero LA, et al. Reporting of conflicts of interest in meta-analyses of trials of pharmacological treatments. JAMA 2011;305:1008-17. doi:10.1001/jama.2011.257

46 Campbell EG, Weissman JS, Ehringhaus S, et al. Institutional academic industry relationships. JAMA 2007;298:1779-86. doi:10.1001/ jama.298.15.1779.

47 Anderson TS, Good CB, Gellad WF. Prevalence and compensation of academic leaders, professors, and trustees on publicly traded US healthcare company boards of directors: cross sectional study. BM/ 2015.351.h4826 doi:10.1136/bmi.h4826

48 Pisano ED, Golden RN, Schweitzer L. Conflict of interest policies for academic health system leaders who work with outside corporations. JAMA 2014:311:1111-2. doi:10.1001/jama.2014.788

49 Hill KP, Ross JS, Egilman DS, Krumholz HM. The ADVANTAGE seeding trial: a review of internal documents. Ann Intern Med 2008;149: 251-8. doi:10.7326/0003-4819-149-4-200808190-00006

50 Krumholz SD, Egilman DS, Ross JS. Study of neurontin: titrate to effect, profile of safety (STEPS) trial: a narrative account of a gabapentin seeding trial. Arch Intern Med 2011;171:1100-7. doi:10.1001/ archinternmed 2011.241

51 Campbell EG, Weissman JS, Ehringhaus S, et al. Institutional academic industry relationships. JAMA 2007;298:1779-86. doi:10.1001/ jama.298.15.1779

52 Campbell EG. Public disclosure of conflicts of interest: moving the policy debate forward. Arch Intern Med 2010;170:667. doi:10.1001/archinternmed.2010.27

53 Okike K, Kocher MS, Wei EX, Mehlman CT, Bhandari M. Accuracy of conflict-of-interest disclosures reported by physicians. N EnglJ Med 2009;361:1466-74. doi:10.1056/NEJMsa0807160

54 Neuman J, Korenstein D, Ross JS, Keyhani S. Prevalence of financial conflicts of interest among panel members producing clinical practice guidelines in Canada and United States: cross sectional study. BM/ 2011:343:d5621. doi:10.1136/bmi.d5621

55 Andreatos N, Zacharioudakis IM, Zervou FN, Muhammed M, Mylonakis E. Discrepancy between financial disclosures of authors of clinical practice guidelines and reports by industry[Baltimore]. Medicine (Baltimore) 2017:96:e5711. doi:10.1097/ MD.0000000000005711

56 Hannon CP, Chalmers PN, Carpiniello MF, Cvetanovich GL, Cole BJ, Bach BRJr. Inconsistencies between physician-reported disclosures a the AAOS annual meeting and industry-reported financial disclosures in the Open Payments Database[Review]. J Bone Joint Surg Am 2016;98:e90. doi:10.2106/JBJS.15.01119

57 Thompson JC, Volpe KA, Bridgewater LK, et al. Sunshine Act: shedding light on inaccurate disclosures at a gynecologic annual meeting. Am J Obstet Gynecol 2016;215:661.e1-7. doi:10.1016/j. ajog.2016.06.015.

58 Donovan A, Kaplan AV. Navigating conflicts of interest for the medical device entrepreneur. Prog Cardiovasc Dis 2012;55:316-20.

Supplementary material: appendices 1-9 